\title{
IMPROVEMENT OF GRAPH INTERPRETATION ABILITY USING HYPERTEXT-ASSISTED KINEMATIC LEARNING AND FORMAL THINKING ABILITY
}

\author{
S. R. Manurung ${ }^{1 *}$, S. Mihardi ${ }^{2}$, N. Y. Rustaman ${ }^{2}$, N. Siregar ${ }^{2}$ \\ ${ }^{1}$ Study Program of Physics, Universitas Negeri Medan, Indonesia \\ ${ }^{2}$ Graduate Program, Universitas Pendidikan Indonesia, Bandung, Indonesia
}

Received: 8 June 2017. Accepted: 4 October 2017. Published: 1 January 2018

\begin{abstract}
The effectiveness of hypertext media in improving graph interpretation ability is investigated in this paper. In addition, joint ability of the formal thinking to improve the graph ability of prospective students is considered. The research design used is the one-group pretest-posttest experimental design is carried out in the research by taking 36 students on from Physics Education Program in one institute for teacher education in Medan. The test consists of graph interpretation ability test in the topic of kinematics and Test of Logical Thinking (TOLT or formal thinking) before learning and graph interpretation ability test after learning. The data are then analysed by using SPSS based two ways Analisys of Variance (ANOVA) method. The results show that the ability to interpretate graph is significantly improved by using hypertext media assisted kinematic learning.
\end{abstract}

\begin{abstract}
ABSTRAK
Pembelajaran kinematik berbantuan media hypertext dalam meningkatkan kemampuan interpretasi grafik diselidiki dalam makalah ini. Selain itu, kemampuan menggabungkan kemampuan berpikir formal dalam pembelajaran terbukti secara empiris dapat meningkatkan kemampuan interpretasi grafik calon mahasiswa. Desain penelitian yang digunakan adalah the one-group pretest-posttest experimental design. Sampel penelitian terdiri dari 36 mahasiswa Program Pendidikan Fisika di salah satu lembaga pendidikan guru di Medan. Tes yang digunakan terdiri dari tes kemampuan interpretasi grafik dalam topik kinematika dan Tes Berpikir Logis (TOLT atau berpikir formal) sebelum belajar dan tes kemampuan interpretasi grafik sebelum dan setelah belajar. Data tersebut kemudian dianalisis dengan menggunakan SPSS dengan metode Analisys of Variance (ANOVA) dua jalur. Hasil penelitian menunjukkan bahwa kemampuan interpretasi grafik secara signifikan dapat ditingkatkan melalui pembelajaran kinematik berbantuan media hypertext.
\end{abstract}

(C) 2018 Jurusan Fisika FMIPA UNNES Semarang

Keywords: Graph Ability; Hypertext Instructional Media; Improving; Kinematics; Learning Assisted

\section{INTRODUCTION}

The topic of kinematics is firstly introduced in the most of Basic Physics classes. Without solid understanding of the concepts of kinematics, students will experience a shortage of the necessary foundation to successfully understand advanced and more abstract physics concepts as stated by Beichner (1994). Graphical representation in kinematics is the most valuable and the most useful tool to represent real

${ }^{*}$ Correspondence Address:

Jl. Willem Iskandar / Pasar V, Medan, Sumatera Utara - Indonesia E-mail: sondangrina@gmail.com world information in comparison to the use of table and algebra. The skill in creating a graph is a key factor in the study of Physics. Drawing and interpreting graphs play a key role in the understanding of science, while the lack of this ability has been proven to be a weakness and may become the factor that limits the learning of scientific concepts (Redding, 2014).

The difficulties in graph interpretation experienced by strudents are as follow: (1) to consider the graph as an image; (2) to distinguish the slope of the graph with the height of the graph; and (3) to consider the graph line is the motion trajectory of an objects (Kekule, 
2014; Mohammed \& Yahya, 2014; Mokros \& Tinker, 1987; McDermott et al., 1987; Goldberg \& Anderson, 1989). Kinematics graphs are often used since they offer some important verbal and algebra description and can be alternatives for students to manipulate the development of the concept (Kekule, 2014 and Beichner, 1994). Many teachers consider that the use of graphs in a laboratory setting is very important in strengthening the graph interpretation ability and developing an understanding to many topics in Physics, especially in motion. This opinion is supported by Vekiri (in Bektasli, 2006), who noted that the use of a graphical display is better than the use of text because the graphical display eases to search and to find the related information.

In the research conducted by Handayani (2014) concerning graph interpretation, there are $49 \%$ of students who are at low criteria, $45 \%$ are at moderate criteria and only $6 \%$ are at high criteria. In the graphical representation, almost no student was able to answer correctly. In creating a graph, mature concept capabilities is required, and it should be applied in the form of graphs based on the concept.

Difficulties in connecting graphs into physical concepts as founded by Mc Dermot et al. (1987) are as follows: (a) distinguishing between the slope and the height of the graph; (b) interpreting the height changes and changes in the slope of the graph; (c) connecting one type of graph to another; (d) matching the narrative information of relevant graphs feature; and (e) interpreting the area under the graph. Difficulties in linking the graph with the real world according to this research has been solved by kinematic learning based hypertext media. According to Kaplan et al. (2014), there are misconceptions of students in understanding of histogram (Manurung, 2013).

To improve the student's abilities in interpreting graphs, therefore in this research is considered by using the hypertext media assisted of physics learning. The fundamental problem in the development of hypertext lies in the inter-relationship of the few aspects, such as nodes which are assumed to be non-linear. Some experts have dealt with the problem using macros chunking strategy (Svec, 1999). In that case, the user's knowledge about the structure underlies the knowledge enabled the user to determine the node to be visited. If the user understands the Toulmin argument (1958), it will easier to get the navigational directions. It is because the troubleshooting scheme over- comes these obstacles through logical rules by applying the pre-structured navigation to provide navigation map which is none other than the underlying knowledge structure of hypertext.

Smith et al. (in Carter, 1997) perceive hypertext as an approach to information management that specializes in how to store data or information in a network node, which are connected to one another by a link. Technical description of hypertext is a group of non-linear text that will be only connected to each other if the reader clicks the labels of the text. By clicking on a node, the reader who is at a particular node will be taken directly to the clicked node. Each node can be connected according to various channels just like a network; it is different to the text in the book that only offers one specific flow of reading. Hypertext has to generate an extraordinary amount of information, in which, each node has multiple relationships (as it can be accessed from any nodes) with a variety of display forms such as text, graphics, audio, video and other data.

Learning with hypertext-based media on argumentative discourse is a kind of explanation based pedagogic teaching which is expected to overcome the difficulties in representing complex concepts of Physics (Erduran et al., 2004). The hypertext can be explained as depicted in Figure 1 which shows the process of building knowledge according to the complexity of the phenomena that can be done according to user navigation. The simulation provides an opportunity for the user to reconstruct the needed information in order to improve his confidence.

Reconstruction and transfer capabilities or also the applications of complex concepts are referred to as advanced knowledge (Spiro \& Jehng, 1990). This complexity can be reduced through a simulation study. Contribution of hypertext media assisted physics learning is to improve the ability of interpretation graph. Hypertext is a method of delivering to a computer with textual units stored at random; line readings follow the lines desired by the reader (Siregar et a.l, 2009). "Hypertext" thus offers a reading with the "jump" capabilities from one point text to another text point or from one topic to another in a semantic space. Through Compiler Guide, The Win Help menu displays help text files, images, links hypertext, keyword search indexes etc; and are similar to the function of hypertext is the key document folder that will help the reader to explore the contents of a particular file. 
Based on the above explanation, it is necessary to perform a certain Physics learning development in order to observe the ability of the students in accepting or rejecting the evidence of a relationship with a rational justification. The study has not been further developed by using a more complex approach to match the complexity of the problem. Thus, the originality of this research lies in the theoretical findings contained in the development of learning programs with the ability to express the abilities of students in solving ill-structured problems.

\section{METHOD}

In the development of hypertext media on the basis of story board, it is conducted as described in Figure 1.

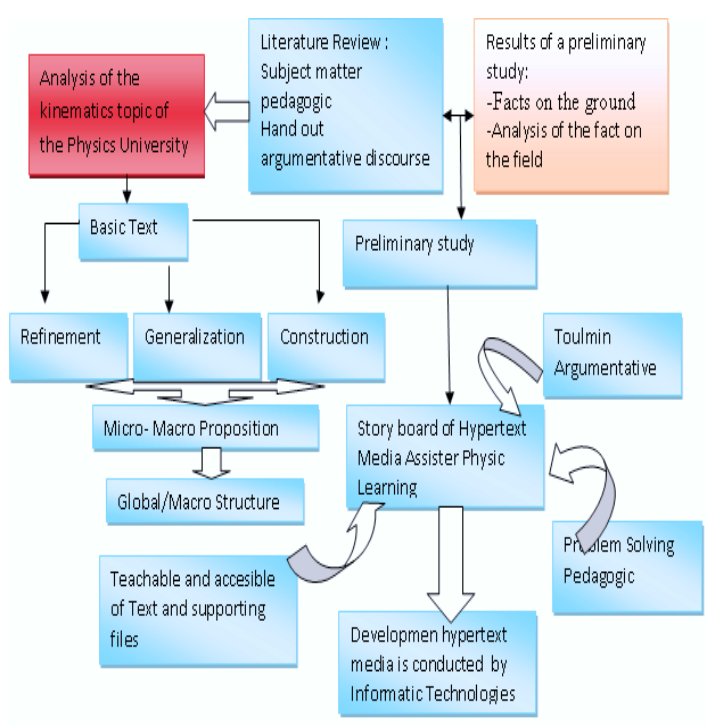

Figure 1. Philosophical grounding of development of hypertext media

Argumentative discourse based Hypertext program design is established from the analysis and findings at the stage of preliminary studies, literature review, and the global/ macro structured. The global/macro structured is derived from three ways, namely: refinement, generalization, and construction. At first, the development of the story board of argumentative discourse and pedagogical problem solving based hypertext media is constructed. Beginning with the original text quoting from a textbook entitled Fundamentals of Physics by Halliday et al., 2011; topics of kinematics subsequently are imparted to establish and to sharp the discourse meaning. Refinement is done according to the criteria of accuracy and clarity. Clarity refers to terminology that does not exceed or reduce the text's meaning that confirms or denies the truth of phenomenonp. Clarity also passes on to the using of verbal action with respect to the main predicate that controls a proposition (Siregar, 1994).

The second application of those criterias is carried out through deletion and/or insertion of the words or phrases. Removal is done on a word or phrase that is excessive and does not favor any particular proposition. It is also made to remove words that have the same meaning as the others. The words that make waste sentences which are difficult or possible to be understood by readers are deleted or inserted into brackets. One word might be removed so that it can be inserted a word or a sentence in order to create sharper proposition without departing from the reference sentence before. Interpolation of words or sentences can also be performed without removal of the first in order to increase the accuracy of the subject matter. Therefore, there is a story board that is charged of argumentative discourse, problem solving pedagogic and global/macro structured of subject matters that are not only easy to learn but also accessible.

Hypertext allows users to realize the potential that there is no longer a passive audience of readers, but as co-author also determines its own sequence of readings. It is the potential with the ability to assemble knowledge with respect to the conditions of complex knowledge. For example, the phenomenon of harmonic motion of a pendulum is usually considered to be simple. Actually, it is not an easy case because it involves a number of representations: (1) the object of phenomena, (2) measurement representation, for example the position of the pendulum on a particular cycle of oscillation, (3) a graphical representation of the phenomenon pendulum according to time and speed. Figure 2 shows the overall inter-relationship of these representations as a complex phenomenon (non-linear).

The above illustration shows the process of building knowledge according to the complexity of the phenomenon that can be done according to user navigation. Simulation provides an opportunity for users to construct and to reconstruct as needed in order to improve his confidence. Reconstruction and transfer capabilities or applications are complex concepts referred to as advanced knowledge (Spiro et al., 1991) which through a simulation study is aimed to reduce the complexity.

The method of this research is quasi-ex- 
periment with the design used for the quantitative research is one group pre-test and post-test (Fraenkel et al., 2012). For the implementation of hypertext in the kinematics learning, the graph of the one group pre-test post-test is as follows. The subject of research for implementation is prospective students in one of teacher education in Medan of 36 students, consisting of 10 male students and 26 female students.

The data were collected by using two research instruments, namely Test of Logical Thinking (TOLT) and test of graph interpretation. Test of graph interpretation consists of 31 multiple choice questions and TOLT consists of 10 items. TOLT is originally developed by Tobin and Capie (1981) and is used to determine the formal reasoning ability of students. TOLT psychometric characteristics have been well documented by the developers. This test was translated and adapted into Turkish and its reliability was found to be 0.81 . In this research, the test consists of 10 items designed to measure the proportional variables (items 1 and 2 ), reasoning control variables (items 3 and 4), probabilistic reasoning (items 5 and 6), correlational reasoning (items 7 and 8 ), and combinatorial reasoning (items 9 and 10). The test consists of problem illustration and multiple choice answers with reasons, except for combinatorial reasoning.

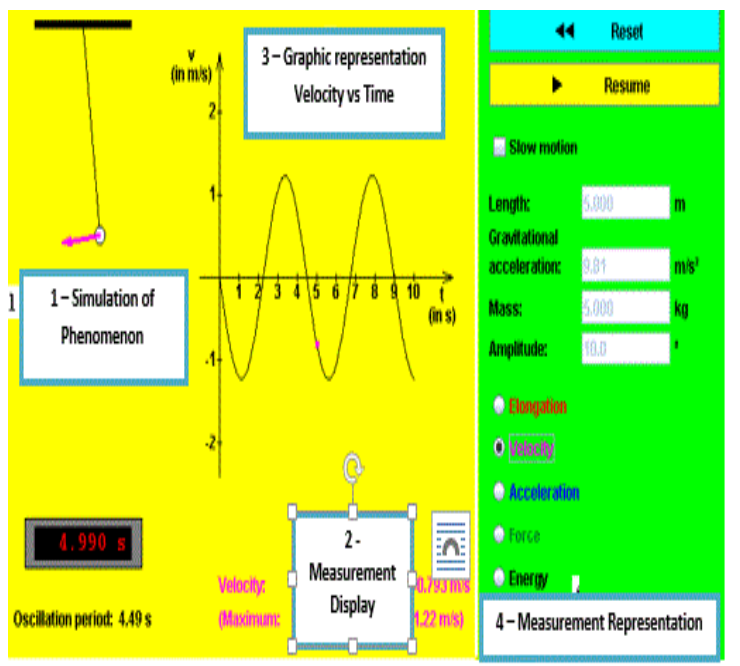

Figure 2. The pendulum phenomenon according to knowledge representation components which construct the basic knowledge about pendulum

\section{RESULTS AND DISCUSSION}

TOLT test consists of 10 items and test of graph interpretation consists of 31 items. The maximum score on the formal thinking ability is 10 , the minimum score is 4 . The mean is 6.58 while the standard deviation is 1.68 . The maximum score on the pre-test of graph interpretation is 12 ; while the minimum score is 3 ; the mean is 7 ; and the standard deviation of 1.84. The maximum score on the post-test of graph interpretation is 16 ; while the minimum score is 8 ; the mean is 12.53; and the standard deviation of 2 . All the results are summarized in Table 1

Table 1. Analysis of Descriptive Statistics of the Three Variabels

\begin{tabular}{|c|c|c|c|c|c|}
\hline Variable & $\begin{array}{l}\text { N (Num- } \\
\text { ber of } \\
\text { samples) }\end{array}$ & Min & Max & Mean & $\begin{array}{l}\text { Std. De- } \\
\text { viation }\end{array}$ \\
\hline Formal & & & & & \\
\hline $\begin{array}{l}\text { Thinking } \\
\text { Ability }\end{array}$ & 36 & 4.00 & 10.00 & 6.5833 & 1.67971 \\
\hline $\begin{array}{l}\text { Pre-Test of } \\
\text { Graph Inter- } \\
\text { pretation } \\
\text { Post-Test of }\end{array}$ & 36 & 3.00 & 12.00 & 7.0000 & 1.83615 \\
\hline $\begin{array}{l}\text { Graph Inter- } \\
\text { pretation }\end{array}$ & 36 & 8.00 & 16.00 & 12.5278 & 2.00693 \\
\hline
\end{tabular}

Collinearity test is conducted to determine whether there is a relationship or correlation between variables. Collinearity can be tested by using the product moment correlation. The summary of the collinearity test is presented in Table 2.

Table 2. Test of Paired Sample t Test

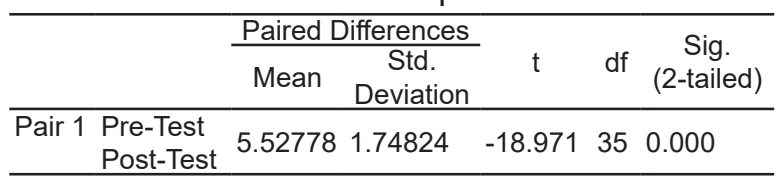

The test results in Table 2 show that the Lower and Upper negative or sig (2-tailed) is $0.000<\alpha=0.05, H_{0}$ is rejected and $H_{A}$ is accepted. There is a difference in the graph interpretation ability before and after the hypertext media assisted learning of kinematics is implemented. Since $t_{\text {calculation }}=-18.97<t_{\text {table }}$ then the test of variance homogeneity between groups uses the Levene 's Test of Equality of Error Variance. The data can be taken to have the same variance if the significant number produced is greater than 0.05 . The summary of the analysis of the variance homogeneity between groups of the learning model is presented in Table 3 
Table 3. Test of Homogeneity of Variances

\begin{tabular}{lcccc}
\hline Variable & $\begin{array}{c}\text { Levene } \\
\text { Statistic }\end{array}$ & df1 & df2 & Sig. \\
\hline PreGraphic & $1.430^{\mathrm{a}}$ & 5 & 29 & 0.243 \\
PosGraphic & $0.849^{\mathrm{b}}$ & 5 & 29 & 0.527 \\
\hline
\end{tabular}

From the output of the variance homogeneity using Levene's test, it is obtained that sig $=0.243$ and $0.527>\alpha(0.01)$. The conclusion is that the variance is homogeneous. Table 3 shows that the Levene's statistics value indicates the significance number of $p>0.05$. This indicates that the null hypothesis which stated that the variance between different groups of learning model was not different is accepted. In other words, the variance between groups of learning model is the same (homogeneous), both for formal thinking skills and for the graph interpretation ability at the pretest and posttest.

Two-way ANOVA test is used to test the hypothesis in this research. Two inter-column main effects are obtained as the treatment variable and inter-row major influence as attribute variables (simple effect) and the column-row major influence as interaction effects. The independent variables are hypertext learning and formal thinking skills, while the dependent variable is graph interpretation ability. The interaction and the significance between main effects of hypertext learning and the formal thinking skills can be obtained in the analysis of variance above, then the test is continued by using the Tukey test between pairs of data in order to determine the group with higher average, as the pairs shown in the following Table 4.

Table 4. The analysis of 2 way ANOVA (Tests of Between-Subjects Effects)

Dependent Variable: Post-test of Graph Interpretation

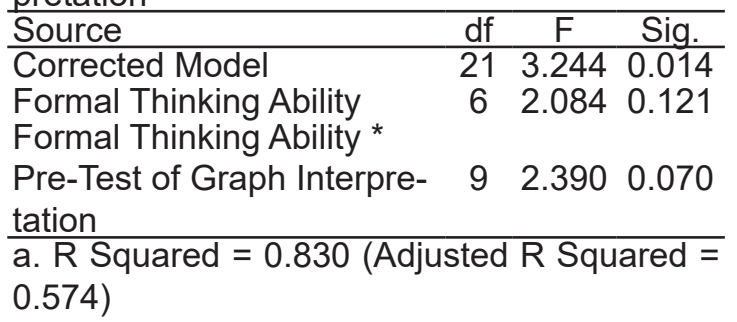

The ANOVA test results formal thinking ability are sig $=0.121$ and $0.121>\alpha(0.05)$, and thus $H_{A}$ is accepted. It can be concluded that the graph interpretation ability not increased for both student with high and low formal thinking ability. ANOVA results of the posttest scores of graph interpretation ability indicate that formal thinking skills are not significant predictor for determining the level of graph interpretation ability. The ANOVA test results in pretest of graph interpretation are sig $=0.002$ and 0.002 $<\alpha(0.05)$, and thus $H_{A}$ is rejected. This result also says that pretest of graph interpretation affects the score of the respondents in graph interpretation test, especially in the posttest condition. However, it is different for both of formal thinking ability and pretest of graph interpretation and is not significant predictor for determining the level of graph interpretation ability.

The results of the research showed that there was similar result of graph interpretation ability for students of high and low formal thinking skills. Furthermore, ANOVA results with formal thinking skills as the independent variable, for the posttest scores of graph interpretation ability, indicated that formal thinking skills was not a significant predictor in determining the level of graph interpretation ability. ANOVA results pre-test of graph interpretation affected the score of the respondents in graph interpretation test, especially in the post-test condition. However, it was different for interaction both of Formal Thinking Ability * Pre-Test of Graph Interpretation not significant predictor for determining the level of graph interpretation ability. McDermott et al. (1987) has exemined the difficulties in connecting the graph with the physical concept and the difficulty in linking the graph to the real world. He had categorized 10 difficulties faced by students in interpreting kinematics graphs, which are divided into two main categories, namely: (1) Difficulty in connecting graphs for physical concepts: a) Distinguishing between the slope and height of the graph, b) Interpreting height changes and changes in slope, c) Connecting one graph type to another, d) Matching narrative information of relevant graph features, e) Interpreting the area under the graph and (2) Difficulty in linking the graph to the real world: a) Indicating a continuous motion as the same as a continuous line, b) Separating the form of a graph of the motion trajectory, c) Showing a negative speed on a speed vs. time graph, d) Showing the acceleration constant on an acceleration vs. time graph. Some other difficulties related with graphs were noted by Mokros \& Tinker (1987), Goldberg \& Anderson (1989) showed that students consider graphs as images. They were confused between the slopes and the height of a graph, and also the form of graphs and trajectories 


\section{CONCLUSION}

Learning through hypertext with object motion simulation as a virtual laboratory was presented in this research. Students can perform measurements and observations of the shown phenomenon. The simulation in this hypertext also showed the graph of movement vs. time. The kinematic concepts in Physics were modeled using algebra, graphs, and motion maps. It was noticed if many appropriate representations were used, then the students showed strong attention in solving kinematic algebraically. The students were expected to solve the problem using graph representation before they solved it using algebraic method. The results showed that sample students preferred the solving method by using graphs and showed a strong improvement in the overall understanding of kinematics concept compared to students who did not receive the treatment

\section{REFERENCES}

Beichner, R.J. (1994). Testing Students' Interpretation of Kinematics Graphs. American Journal of Physics, 62 (8), $750-762$.

Bektasli, B. (2006). The Relationships Between Spatial Ability, Logical Thinking, Mathematics Performance and Kinematics Graph Interpretation Skills Of 12th Grade Physics Students. Dissertation. The Ohio State University.

Carter, L.M. (1997). Arguments in Hypertext: Order and Structure in non-sequential Essays. Dissertation of University of Texas, Austin

Erduran, S., Simon, S., \& Osborne, J. (2004) TAPping into Argumentation: Developments in the Application of Toulmin's Argument Pattern for Studying Science Discourse. Science Education, 88(6), 915-933.

Fraenkel, J.R., Wallen, N.E., \& Hyun, H.H. (2012). How To Design and Evaluate Research in Science Education. (8th Ed.) New York: McGraw - Hill, Inc.

Goldberg, F.M., \& Anderson, J.H. (1989). Student Difficulties with Graphical Representations of Negative Values of Velocity. The Physics Teacher 27, $254-60$.

Handayani, N. (2014). Identifikasi Pemahaman Siswa terhadap konsep Rangkaian Listrik searah berbasis representasi grafik dan verbal. Final Project (Unpublished). Universitas Islam Negeri Sunan Kalijaga, Yogyakarta.

Kaplan, J.J., Gabrosek, J.G., Curtiss, P., and Malone, C. (2014). Investigating student un- derstanding of histograms. Journal of Statistics Education, 22( 2) 1-30.

Kekule, M. (2014) Students' approaches when dealing with kinematics graphs explored by eye-tracking research method. Proceedings of the Frontiers in Mathematics and Science Education Research Conference 1-3 May 2014, Famagusta, North Cyprus.

Manurung, S.R. (2013). Pengembangan Pembelajaran Kinematika Melalui Hiperteks Berdasarkan Pedagogi Pemecahan Masalah Bermuatan Argumentasi Toulmin. Dissertation. Bandung: UPI.

McDermott, L. C., Rosenquist, M.L \& van Zee, E.H. (1987). Student Difficulties in Connecting Graphs and Physics: Examples from Kinematics. American Journal of Physics, 55 (6), 503513.

Mohammed, S.A., \& Yahya, A.A. (2014). The Effect of Computer Simulation on Al-Hussein Bin Talal Unıversıty. Student's Understanding of Electricity and Magnetism Concepts and their Attitudes toward Physics Learning. International Journal of Educational Research and Technology, 5 (1) March 2014: 54-60.

Mokros, J. R., \& Tinker, R. F. (1987). The impact of microcomputer-based labs on children's ability to interpret graphs. Journal of Research in Science Teaching, 24, 369-383.

Redding, C.W. (2014). Effect of Predicting Motion on Student Uderstanding of Kinematic Graphis. Thesis. Louisiana State University.

Siregar, N., Kurnia, \& Setiawan, W. (2009). Pedagogi E-Learning: Antar-Muka Pembaca Sebagai Dasar. Penelitian FPMIPA UPI. (Unpublished).

Spiro, R., \& Jehng, J. (1990). Cognitive flexibility and hypertext: Theory and technology for the non-linear and multi-dimensional traversal of complex subject matter. In D.Nix \& R. Spiro (Eds.), Cognition, education, multimedia: Exploring ideas in high technology (pp. 163205). Hillsdale, NJ: Erlbaum.

Svec, M. (1999). Improving graphical interpretation skills and understanding of motion using microcomputer based laboratories. Electronic Journal of Science Education, 3 (4). ejse. southwestern.edu/article/view/7611/5378. (html version)

Tobin, K., \& Capie, W. (1981). The development and validation of a group test of logical thinking. Educational and Psychological Measurement, 41, 413-423.

Toulmin, S. E. (1958). The Uses of Argument. Cambridge: Cambridge University Press. 